\title{
THYROID DISORDERS IN HIV PATIENTS- A SINGLE CENTRE CROSS-SECTIONAL STUDY
}

\author{
Devinder Kumar Vohra1 ${ }^{1}$ Gaurav Garg², Yogita Singh ${ }^{3}$, Snehlata Verma ${ }^{4}$, Rahul Goel ${ }^{5}$, Alka Srivastava ${ }^{6}$
}

${ }_{1}^{1}$ Associate Professor, Department of Medicine, LLRM Medical College, Meerut, Uttar Pradesh.

${ }^{2}$ Associate Professor, Department of Medicine, LLRM Medical College, Meerut, Uttar Pradesh.

${ }^{3}$ Associate Professor, Department of Medicine, LLRM Medical College, Meerut, Uttar Pradesh.

${ }^{4}$ Assistant Professor, Department of Medicine, LLRM Medical College, Meerut, Uttar Pradesh.

5Junior Resident, Department of Medicine, LLRM Medical College, Meerut, Uttar Pradesh.

${ }^{6}$ Lecturer, Department of Physiology, LLRM Medical College, Meerut, Uttar Pradesh.

\section{BACKGROUND}

ABSTRACT

There is report of increasing prevalence of thyroid disorders in HIV positive patients. Currently, there is insufficient data to recommend routine screening for thyroid disorders in asymptomatic HIV patients; hence, this study was undertaken to resolve these issues.

\section{MATERIALS AND METHODS}

This is a comparative descriptive study of 150 seropositive HIV patients, which was taken for convenience conducted at LLRM Medical College and SVBP Hospital, Meerut, U.P.

\section{RESULTS}

Overt hypothyroidism was found in 3.33\% patients, subclinical hypothyroidism was found in 9.33\% patients, isolated low FT4 was found in $2.66 \%$ patients, while sick euthyroid syndrome was found in $26 \%$ patients. None of the patients was found to be having hyperthyroidism. As the disease progressed FT4 and FT3 levels decreased, while TSH level increased. A direct positive correlation between FT4, FT3 and CD4 count was established, while a negative correlation between S. TSH and CD4 count was found. Mean FT3 and FT4 levels were lower in patients on HAART, while mean TSH level was higher in patients on HAART.

\section{CONCLUSION}

Thyroid dysfunction in HIV patients was largely asymptomatic. There was a direct correlation between WHO clinical stage and FT3 and FT4 levels. TSH level increased as CD4 count decreased. Patients on HAART had a higher prevalence of subclinical hypothyroidism.

\section{KEYWORDS}

HIV- Human Immunodeficiency Virus, TSH, HAART, FT3.

HOW TO CITE THIS ARTICLE: Vohra DK, Garg G, Singh Y, et al. Thyroid disorders in HIV patients- a single centre cross-sectional study. J. Evolution Med. Dent. Sci. 2018;7(16):1962-1965, DOI: 10.14260/jemds/2018/441

\section{BACKGROUND}

The prevalence of human immunodeficiency virus (HIV) infection in India is estimated to be 2.4 million. ${ }^{1} \mathrm{HIV}$ infection can lead to involvement of various organs and systems including endocrine glands. Alteration in endocrine functions may be due to the possible relationship between the immune and endocrine systems, direct involvement of the glands by the HIV itself, opportunistic infections or malignancies, highly active anti-retroviral therapy (HAART) and drugs used to treat the opportunistic infections. ${ }^{2}$ Although, the prevalence of overt thyroid disease does not appear to be significantly increased as compared to general population, subtle thyroid dysfunction is common, believed to occur in as many as $35 \%$ of all HIV infected individuals.3-6 Earlier studies have evaluated the possible relationship of thyroid dysfunction in HIV. In India, there are only very few reports on thyroid dysfunction in HIV patients.

'Financial or Other Competing Interest': None.

Submission 05-03-2018, Peer Review 29-03-2018,

Acceptance 04-04-2018, Published 16-04-2018.

Corresponding Author:

Dr. Gaurav Garg,

LG-3, LLRM Medical College,

Meerut, Uttar Pradesh.

E-mail: drgaurav.g9@gmail.com

DOI: $10.14260 /$ jemds $/ 2018 / 441$

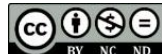

The prevalence and relationship of thyroid autoantibodies in various stages of disease and therapy has not been studied. There was no report of hyperthyroidism in these publications, despite reports of resurgence of autoimmunity leading on to Graves' disease in immune reconstitution inflammatory syndrome. So further studies are required to confirm this. Hence, the present study is designed to answer the above uncertainties. This study also assesses whether universal screening of thyroid function could be enforced in HIV patients.

\section{Aims and Objectives}

1. To study the thyroid dysfunction, both clinical and biochemical in HIV positive patients.

2. To correlate the thyroid function changes in these patients with their CD4 cell count, WHO clinical stage and duration of HAART.

\section{MATERIALS AND METHODS}

This is a comparative descriptive study of 150 seropositive HIV patients, which was taken for convenience conducted at LLRM Medical College and SVBP Hospital, Meerut, U.P. Duration of the study was one year from Nov. 2016 to October 2017. The Institutional Ethics Committee approval was taken. Informed consent was obtained from all patients and patient confidentiality was maintained. 


\section{Inclusion Criterion}

1. Subjects with HIV serology positive by ELISA test.

2. Age greater than or equal to 18 years.

3. Subjects consenting to take part in the study.

4. Clinically stable with vital signs within normal limits.

\section{Exclusion Criteria}

1. Known cases of thyroid disorder.

2. Patients on drugs altering thyroid hormones metabolism and stavudine-based antiretroviral drugs.

3. Diabetic patients.

4. Abnormal liver function tests with SGOT/ SGPT levels greater than 3 times normal range and abnormal renal function tests with serum creatinine greater than 1.6 $\mathrm{mg} \%$.

Based on Inclusion and Exclusion Criteria, Patients were Grouped into-

- Group A- Treatment naive. $(n=50)$

- Group B- Taking HAART for less than a year $(n=50)$

- Group C-Taking HAART for a year or more $(n=50)$

All patients were evaluated with history taking, physical examination and biochemical investigations. CD4 count was done in all the patients and patients were categorised as per WHO clinical stage. FT3, FT4 and TSH were measured at the endocrinology laboratory of our hospital by chemiluminometric immunoassay. The coefficient of variance for FT3 was $1.71-3.71 \mathrm{pg} / \mathrm{dL}$, for FT4 was $0.70-1.48 \mathrm{ng} / \mathrm{dL}$ and that for TSH was $0.3500-4.9400 \mu \mathrm{IU} / \mathrm{mL}$.

\section{Statistical Analysis}

Data analysis was done with the help of SPSS software version 15 and Sigma plot version 11. Quantitative data is presented with the help of mean and standard deviation, comparison between study groups was done with the help of unpaired T-test or Mann-Whitney test as per the result of normality test. Pearson correlation coefficient test was used to describe correlation between continuous variables like thyroid function test and CD4 count. Qualitative data is presented with the help of frequency and percentage table, association among study groups is assessed with the help of chi-square test. P-value $<0.05$ is taken as significant.

\section{RESULTS}

Majority patients in the study were males (74\%) with age group 21 - 40 years $(77 \%)$, most of the patients were in the weight group 40 - $60 \mathrm{~kg}$ (97\%), only 1 patient enrolled in the study had weight $>60 \mathrm{~kg}$ while 3 patients had weight $<40 \mathrm{~kg}$. Number of patients in each group enrolled was 50.

Out of 150 patients 74 (49\%) had HIV duration less than 1 year, while $76(51 \%)$ had HIV duration more than 1 year. 84 patients $(56 \%)$ had CD4 count $<350 / \mathrm{mm}^{3}$, while 38 patients (25\%) had CD4 count between $351-700 / \mathrm{mm}^{3}$ and 28 patients $(19 \%)$ had CD4 count $>700 / \mathrm{mm}^{3}$.

Majority of patients enrolled for the study were in WHO clinical stage III (37\%), while $24 \%$ patients were in WHO stage II, $21 \%$ patients were in stage IV and $18 \%$ patients were in WHO stage I. Sick euthyroid syndrome was the most common thyroid function abnormality in HIV positive patients 39 (26\%) followed by subclinical hypothyroidism 14 $(9.33 \%)$. None of the patient was found to have hyperthyroidism and majority of them were male (74\%), [Table 1]

\begin{tabular}{|c|c|c|c|}
\hline Thyroid Disorder & No. of Patients & Males & Females \\
\hline Overt hypothyroidism & $5(3.33 \%)$ & 2 & 3 \\
\hline $\begin{array}{c}\text { Subclinical } \\
\text { hypothyroidism }\end{array}$ & $14(9.33 \%)$ & 8 & 6 \\
\hline Isolated low F-T4 & $4(2.66 \%)$ & 3 & 1 \\
\hline $\begin{array}{c}\text { Sick Euthyroidism } \\
\text { (Isolated low FT3) }\end{array}$ & $39(26 \%)$ & 29 & 10 \\
\hline Hyperthyroidism & 0 & 0 & 0 \\
\hline Euthyroidism & $88(58.66 \%)$ & 69 & 19 \\
\hline Total & $\mathbf{n = 1 5 0}$ & $\begin{array}{c}\mathbf{1 1 1} \\
\mathbf{( 7 4 \% )}\end{array}$ & $\begin{array}{c}\mathbf{3 9} \\
(\mathbf{2 6 \% )}\end{array}$ \\
\hline
\end{tabular}

Table 1. Prevalence of Thyroid Dysfunction in the Study

Most of the HIV patients who had thyroid dysfunction have CD4 count $<350$ [Table 2] and thyroid function abnormalities were more common in patients on ART when compared with patients not on ART [Table 3].

\begin{tabular}{|c|c|c|c|c|}
\hline $\begin{array}{c}\text { CD4 } \\
\text { Count } \\
\left(\mathbf{m m}^{3} \text { ) }\right.\end{array}$ & $\begin{array}{c}\text { Overt } \\
\text { Hypo- } \\
\text { thyroidism }\end{array}$ & $\begin{array}{c}\text { Subclinical } \\
\text { Hypo- } \\
\text { thyroidism }\end{array}$ & $\begin{array}{c}\text { Isolated } \\
\text { Low } \\
\text { FT4 }\end{array}$ & $\begin{array}{c}\text { Sick } \\
\text { Euthyroidism } \\
\text { (Isolated } \\
\text { Low FT3) }\end{array}$ \\
\hline$<350$ & $4(80 \%)$ & $12(86 \%)$ & $1(25 \%)$ & $37(95 \%)$ \\
\hline $351-700$ & $1(20 \%)$ & $2(14 \%)$ & $3(75 \%)$ & $2(5 \%)$ \\
\hline$>700$ & 0 & 0 & 0 & 0 \\
\hline Total & $\mathbf{n = 5}$ & $\mathbf{n = 1 4}$ & $\mathbf{n = 4}$ & $\mathbf{n = 3 9}$ \\
\hline \multicolumn{6}{|c|}{ Table 2. Distribution of Thyroid Dysfunction } \\
according to CD4 Count \\
\hline
\end{tabular}

\begin{tabular}{|c|c|c|c|c|}
\hline $\begin{array}{c}\text { ART } \\
\text { Group }\end{array}$ & $\begin{array}{c}\text { Overt } \\
\text { Hypo- } \\
\text { thyroidism }\end{array}$ & $\begin{array}{c}\text { Subclinical } \\
\text { Hypo- } \\
\text { thyroidism }\end{array}$ & $\begin{array}{c}\text { Isolated } \\
\text { Low } \\
\text { F-T4 }\end{array}$ & $\begin{array}{c}\text { Sick } \\
\text { Euthyroidism } \\
\text { (Isolated Low } \\
\text { FT3) }\end{array}$ \\
\hline $\mathrm{A}(\mathrm{n}=50)$ & 0 & 0 & 0 & $4(10.25 \%)$ \\
\hline $\mathrm{B}(\mathrm{n}=50)$ & $1(20 \%)$ & $5(36 \%)$ & $1(25 \%)$ & $17(43 \%)$ \\
\hline $\mathrm{C}(\mathrm{n}=50)$ & $4(80 \%)$ & $9(64 \%)$ & $3(75 \%)$ & $18(46 \%)$ \\
\hline Total & $\mathbf{n = 5}$ & $\mathbf{n = 1 4}$ & $\mathbf{n = 4}$ & $\mathbf{n}=\mathbf{3 9}$ \\
\hline \multicolumn{5}{|c|}{ Table 3. Distribution of Thyroid Dysfunction } \\
according to ART Group \\
\hline
\end{tabular}

Thyroid disorders were more prevalent in Group B (patients on HAART $<1$ year) and Group $\mathrm{C}$ as compared to Group A (treatment naïve patients) and the difference was clinically significant ( $p$ value $<0.05$ ), [Table 4 and 5].

\begin{tabular}{|c|c|c|c|}
\hline $\begin{array}{c}\text { Thyroid } \\
\text { Function Test } \\
\text { (Mean } \pm \text { SD) }\end{array}$ & $\begin{array}{c}\text { Group A } \\
(\mathbf{n = 5 0 )}\end{array}$ & $\begin{array}{c}\text { Group B } \\
(\mathbf{n = 5 0 )}\end{array}$ & $\begin{array}{c}\text { Unpaired T } \\
\text { Test } \\
\text { P value }\end{array}$ \\
\hline TSH & $\begin{array}{c}1.6461 \pm \\
0.8099\end{array}$ & $\begin{array}{c}2.8172 \pm \\
1.6795\end{array}$ & $\mathrm{p}=0.001$ \\
\hline FT3 & $\begin{array}{c}2.5382 \pm \\
0.4521\end{array}$ & $\begin{array}{c}2.0304 \pm \\
0.5356\end{array}$ & $\mathrm{p}=0.001$ \\
\hline \multirow{2}{*}{ FT4 } & $\begin{array}{c}1.1518 \pm \\
0.20182\end{array}$ & $\begin{array}{c}1.0354 \pm \\
0.2104\end{array}$ & $\mathrm{p}=0.008$ \\
\hline \multicolumn{4}{|c|}{ Table 4. Correlation of Thyroid Dysfunction } \\
between Group A and Group B \\
\hline
\end{tabular}




\begin{tabular}{|c|c|c|c|}
\hline $\begin{array}{c}\text { Thyroid } \\
\text { Dysfunction } \\
\text { (Mean } \pm \text { SD) }\end{array}$ & $\begin{array}{c}\text { Group A } \\
\text { (n=50) }\end{array}$ & $\begin{array}{c}\text { Group C } \\
\mathbf{( n = 5 0 )}\end{array}$ & $\begin{array}{c}\text { Unpaired } \\
\text { T Test } \\
\text { P value }\end{array}$ \\
\hline \multirow{2}{*}{ TSH } & $\begin{array}{c}1.6461 \pm \\
0.8099\end{array}$ & $\begin{array}{c}3.7062 \pm \\
1.9796\end{array}$ & $\mathrm{p}=0.001$ \\
\hline \multirow{2}{*}{ FT3 } & $\begin{array}{c}2.5382 \pm \\
0.4521\end{array}$ & $\begin{array}{c}1.9006 \pm \\
0.4930\end{array}$ & $\mathrm{p}=0.001$ \\
\hline \multirow{2}{*}{ FT4 } & $1.1518 \pm$ & $0.8801 \pm$ \\
0.20182 & 0.1749 & $\mathrm{p}=0.001$ \\
\hline \multicolumn{4}{|c|}{ Table 5. Correlation of Thyroid Dysfunction between } \\
Group A and Group C \\
\hline
\end{tabular}

Figure 1 shows that all of the 5 patients who had overt hypothyroidism were in WHO clinical stage IV and majority of patients with thyroid function abnormalities belonged to WHO stage III and IV.

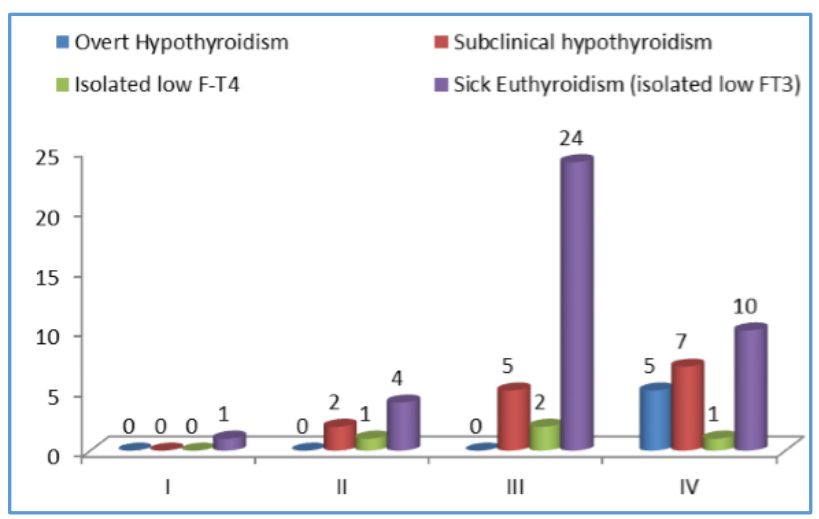

Figure 1. Distribution of Thyroid Dysfunction according to WHO Clinical Stage

All the 5 patients who had overt hypothyroidism had HIV duration $>1$ year, while 10/14 (71\%) patients had subclinical hypothyroidism had HIV duration > 1 year, 3/4 (75\%) patients with isolated low FT4 had HIV duration $>1$ year and $23 / 39$ (59\%) patients with sick euthyroid syndrome had HIV duration $>1$ year (Figure 2).

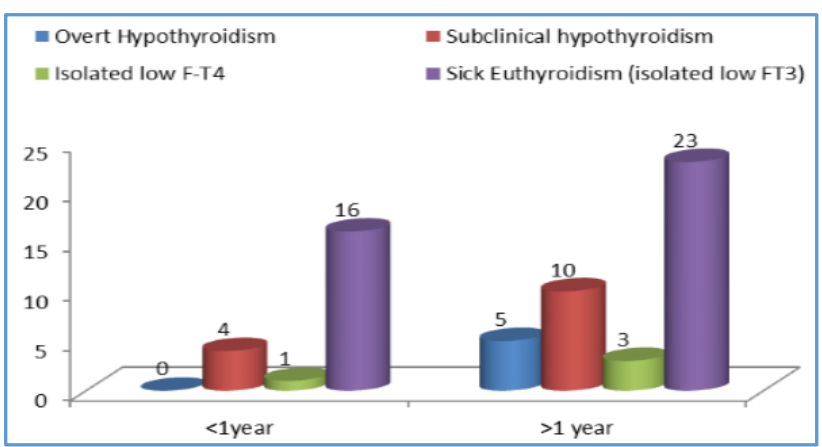

Figure 2. Distribution of Thyroid Dysfunction according to duration of HIV

Above observation shows that thyroid disorders in HIV patients become more common as duration of disease increases. On correlating the level of FT3, FT4 and TSH with the WHO stage shows that the level of FT3 and FT4 goes on decreasing from stage I to stage IV ( $p$ value $=0.000$ ) and the level of TSH goes on increasing from stage I to stage IV ( $p$ value $=0.000$ ). Thus, as the clinical severity of HIV infection increases, the level of FT3 and FT4 decreases and TSH increases.
On correlating FT3, FT4 and TSH level with CD4 count, a positive correlation between FT3 level and CD4 count is found (Pearson correlation coefficient $=0.4249, \mathrm{p}$ value $=$ 0.000), a positive correlation between FT4 level and CD4 count (Pearson correlation coefficient $=0.2972$, $p$ value $=$ 0.0001 ) is also found, while a negative correlation between S.TSH level and CD4 count (Pearson correlation coefficient= $0.4741, \mathrm{p}$ value $=0.000$ ) is also established. Above results show that as the CD 4 count decreases in HIV positive patients the FT3 and FT4 level also decreases, while S. TSH level increases.

On correlating thyroid function abnormalities in patients on HAART and patients not on HAART a significant difference ( $p$ value $=0.001$ ) is found in mean FT3, FT4 and TSH level between the two groups, which shows that thyroid function abnormalities are more prevalent in patients on HAART [Table 6].

\begin{tabular}{|c|c|c|c|}
\hline \multirow{2}{*}{$\begin{array}{c}\text { Study } \\
\text { Parameter }\end{array}$} & $\begin{array}{c}\text { On HAART } \\
\text { (Mean } \pm \text { SD) }\end{array}$ & $\begin{array}{c}\text { Not on HAART } \\
\text { (Mean } \pm \text { SD) }\end{array}$ & $\begin{array}{c}\text { T-test } \\
\text { P value }\end{array}$ \\
\hline FT3 & $1.96 \pm 0.51$ & $2.55 \pm 0.44$ & 0.0001 \\
\hline FT4 & $0.95 \pm 0.21$ & $1.16 \pm 0.20$ & 0.0001 \\
\hline TSH & $3.2894 \pm 1.86169$ & $1.5902 \pm 0.7763$ & 0.0001 \\
\hline \multicolumn{4}{|c|}{ Table 6. Correlation between Thyroid Dysfunction } \\
according to HAART \\
\hline
\end{tabular}

\section{DISCUSSION}

The present study enumerates the prevalence of various thyroid function disorders in HIV positive patients and their association with various factors like CD4 count, WHO clinical stage, duration of HIV and HAART. In the present study, the prevalence of overt hypothyroidism was $3.33 \%$, subclinical hypothyroidism was $9.33 \%$, isolated low FT4 in $2.66 \%$ patients, while sick euthyroid syndrome was found in $26 \%$ patients.

Some other studies such as a study Varanasi, ${ }^{7}$ reported $30 \%$ prevalence of subclinical hypothyroidism and $10.66 \%$ prevalence of overt hypothyroidism. In this study, patients having acute illness which can alter the thyroid function were also included. The difference in results may also be due to ethnical difference and differences in the sample size. None of the patients were found to be hyperthyroid in the present study. Similarly, earlier studies from India and western countries also did not report hyperthyroidism in any of the patients. We also noted a positive correlation between FT3, FT4 level and the CD4 count, while a negative correlation was noted between TSH and CD4 count. A study done by Mala V Kaneria et $\mathrm{al}^{8}$ reported a similar correlation.

The present study also shows that as the HIV patients deteriorate clinically as reflected by WHO clinical staging, the prevalence of thyroid function abnormalities increases. Earlier studies also reported similar results and thyroid function abnormalities were more common in patients receiving HAART than patients not receiving HAART. This may be due to the direct effect of antiretroviral drugs on thyroid metabolism.

The role of HAART was also confirmed by a recent report that interruption of HAART was associated with a normalisation of thyroid function test. ${ }^{9}$ Immune reconstitution autoimmune thyroid disease (AITD) (Grave's disease, thyrotoxicosis and hypothyroidism) was found to be 
$3 \%$ for women and $0.2 \%$ for men. The median duration of immune reconstitution was 17 months. ${ }^{10-12}$

Patients with lower CD4 count at baseline who experienced greater increments in the CD4 counts following HAART were more likely to develop AITD. But none of the patients in the present study was found of have immune reconstitution syndrome. We also found that thyroid function abnormalities become more prevalent, as duration of disease increases. This may be due to increasing incidence of opportunistic infections and decreasing CD4 count, as the duration of the infection increases.

\section{Certain Limitations of our Study were-}

1. As study design was a cross-sectional, we could not derive pathogenesis of thyroid dysfunction.

2. As this study was conducted in a tertiary care hospital, the study group does not show the population characteristics and the patient's study could not be equally distributed for HIV associated conditions like stage of infection, CD4 count, HAART etc.

3. TFT was measured at one point in time, limiting the robustness of the relationship being considered between the variable and the thyroid function tests.

Hence, studies with larger sample size from general population with longitudinal follow-up of the patients are needed to confirm the results of the present study.

\section{CONCLUSION}

Abnormal thyroid function tests are common in HIV infected patients. Sick euthyroid syndrome, subclinical hypothyroidism and overt hypothyroidism are most common thyroid function disorders in HIV positive patients and these disorders are more prevalent in patients who have more severe disease and are on antiretroviral therapy.

Thus, patients having HIV duration $>1$ year, CD4 count < $350 / \mathrm{mm}^{3}$ in WHO clinical stage III and IV and patients on HAART may require regular monitoring of thyroid function tests. Currently, there is insufficient evidence in favour of screening of thyroid abnormalities in asymptomatic HIV infected patients. Larger studies are needed to examine the epidemiology and health consequences of thyroid dysfunction in HIV patients and to better inform screening and treatment guidelines.

\section{REFERENCES}

[1] Global report: UNAIDS report on the global AIDS epidemic. Annexure I: 2010: p. 187.

[2] Dobs AS, Dempsey MA, Ladenson PW, et al. Endocrine disorders in men infected with human immunodeficiency virus. American Journal of Medicine 1988;84(3 Pt 2):611-16.

[3] Mayer KH, Hoffmann CJ, Brown TT. Thyroid function abnormalities in HIV infected patients. Clin Infected Dis 2007;45(4):488-94.

[4] Calza L, Manfredi R, Chiodo F. Subclinical hypothyroidism in HIV infected patients receiving highly active antiretroviral therapy. Journal of Acquired Immune Deficiency Syndromes 2002;31(3):361-3.

[5] Pearce EN. Diagnosis and management of thyrotoxicosis. BMJ 2006;332(7554):1369-73.

[6] Sharma N, Sharma LK, Dutta D, et al. Prevalence and predictors of thyroid dysfunction in patients with HIV infection and acquired immunodeficiency syndrome: an Indian perspective. Article ID 517173, Journal of Thyroid Research 2015;2015: p. 9.

[7] Meena LP, Rai M, Singh SK, et al. Endocrine changes in male HIV patients. JAPI 2011;59:365-6, 371.

[8] Kaneria MV, Kahalekar VV. A study of thyroid dysfunction in HIV infected patients in a tertiary care hospital. Int J Adv Med 2016;3(3):708-15.

[9] Madeddu G, Spanu A, Chessa F, et al. Thyroid function in human immunodeficiency virus patients treated with highly active antiretroviral therapy (HAART): a longitudinal study. Clinical Endocrinology (Oxf) 2006;64(4):375-83.

[10] Varthakavi PK. Thyroid dysfunction in HIV-AIDS. JAPI 2009;57:503-4.

[11] Hirsch HH, Kaufmann G, Sendi P, et al. Immune reconstitution in HIV-infected patients. Clin Infect Dis 2004;38(8):1159-66.

[12] Battegay M, Dreschsler H. Clinical spectrum of the immune restoration inflammatory syndrome. Curr Opin HIV AIDS 2006;1(1):56-61. 